LETTERS TO THE EDITOR

\section{Hevea brasiliensis Rather Than Latex}

Bourrain JL

Allergologie

Hôpital Arnaud de Villeneuve

371 Avenue du doyen Gaston Giraud

34295 Montpellier Cedex 5, France

E-mail:jl-bourrain@chu-montpellier.fr

J Investig Allergol Clin Immunol 2016; Vol. 26(4): 278

doi: $10.18176 /$ jiaci.0067

Key words: Allergy. Hevea brasiliensis. Latex. Natural rubber latex.

Palabras clave: Alergia. Hevea brasiliensis. Látex. Caucho natural.

Dear Editor,

The case report of Sanchez et al [1] about cross-reactivity between latex and cassava leads me to make a general remark about the term "latex".

While this word is widely used in the allergy literature, it constitutes an abuse of language that is not only a source of inaccuracy, but could also lead to confusion or error. Indeed, the definition of latex involves 2 components: emulsions of variable composition with a milky appearance produced by specific plants and aqueous emulsions produced by certain synthetic macromolecular substances.

Therefore, we can speak of synthetic latex, which is completely different in terms of chemical structure from the type of latex quoted in the above article. In fact, even the use of the term "natural rubber latex" is not sufficient, because there are many other latex plants, some of which could be used in manufacturing without necessarily being chemically related. Guayule is an example.

In the age of molecular allergology, I believe that we should use accurate terminology. In this case, it is indeed a crossreaction between proteins of Hevea brasiliensis and another of cassava, and the term we should use in our publications and in our daily clinical practice should be "Hevea protein" or "latex from Hevea."

\section{References}

1. Sánchez D, Sus S, Ortiz B, Sánchez J, Cardona R. Crossreactivity Between Cassava and Latex in a Colombian Patient With an Anaphylactic Reaction. J Investig Allergol Clin Immunol. 2015;25(6):453-5.

\author{
Reply to "Hevea brasiliensis Rather Than Latex" \\ Cardona R, Sánchez J \\ E-mail:rcv2016udea@gmail.com \\ J Investig Allergol Clin Immunol 2016; Vol. 26(4): 278 \\ doi: $10.18176 /$ jiaci.0071 \\ Key words: Allergy. Latex. Cassava. Hevea. \\ Palabras clave: Alergia. Látex. Yuca. Hevea.
}

We thank Dr. Jean Luc Bourrain for his pertinent observation,

"Latex allergy" is a global term that is often used when referring to type I hypersensitivity to Hevea brasiliensis. Since other types of latex do not generally produce reactions or are classed as being type I hypersensitivity, I feel that the probability of confusion is low. Nevertheless, in our article, we clarified which types of products were associated with anaphylactic reaction and we confirm that the patient in question had come into contact with latex from Hevea brasiliensis. For that reason, we use the term latex allergy, although we do agree with Dr. Bourrain that terminology should be more precise not only for latex, but also for other common expressions in the scientific literature and in clinical practice. 